\title{
Kesiapan Fisik dan Pengetahuan Remaja Perempuan Sebagai Calon Ibu dalam Membina Tumbuh Kembang Balita dan Faktor-faktor yang Mempengaruhinya
}

\author{
Wan Nedra, Soedjatmiko, Agus Firmansyah
}

Latar Belakang. Dua puluh satu persen penduduk Indonesia adalah remaja. Hanya $11,6 \%$ lulusan SMU yang melanjutkan ke perguruan tinggi, yang tidak melanjutkan antara lain memasuki jenjang perkawinan, padahal perkawinan pada usia muda sangat mengundang risiko yang tidak bisa diabaikan. Mereka yang memasuki jenjang perkawinan, umumnya mempunyai kesiapan fisik dan pengetahuan yang belum memadai, sehingga perlu disiapkan. Seorang ibu yang mempunyai pengetahuan yang baik akan menghasilkan tumbuh-kembang balita yang baik pula, khususnya dalam tiga tahun pertama usia anak.

Tujuan Pustaka. Penelitian ini bertujuan untuk melihat kesiapan fisik, dan pengetahuan remaja perempuan terhadap tumbuh kembang balita.

Metoda. Penelitian merupakan studi analitik potong lintang pada remaja perempuan siswi SMU di 7 sekolah di Jakarta Timur, yang dilaksanakan Januari 2006 sampai Maret 2006. Setelah mendapat persetujuan penelitian maka dilakukan pemeriksaan fisis dan pengambilan sampel darah untuk pemeriksaan hemoglobin. Selanjutnya responden mengisi kuesioner untuk mengetahui pengetahuan mereka tentang tumbuh kembang balita.

Hasil. Dari 300 responden diperoleh rerata umur 17,2 tahun, suku Jawa 40,2 \% dan umumnya tinggal dengan orang tua $(75,7 \%)$. Responden yang anemia sebanyak $25,36 \%$, gizi kurang $18,5 \%$, gizi baik $74,4 \%$, gizi lebih $4,7 \%$, dan obesitas $2,3 \%$. Sumber informasi yang berhubungan dengan masalah tumbuh kembang balita hanya $13,6 \%$ berasal dari sumber formal yaitu orang tua, guru dan tenaga kesehatan. Remaja yang berpengetahuan tinggi didapatkan sebanyak $19 \%$, pengetahuan sedang $33 \%$, dan pengetahuan rendah $48 \%$. Remaja yang tidak siap menjadi calon ibu secara fisik didapatkan pada $42,3 \%$. Kesiapan pengetahuan didapatkan pada $63,7 \%$ remaja, sedangkan kesiapan fisik dan pengetahuan yang memadai didapatkan pada $31,3 \%$. Tidak ada hubungan antara kesiapan responden untuk menjadi calon ibu dengan demografi keluarga dan sumber informasi.

Kesimpulan. Lebih dari separuh remaja $(57,7 \%)$ telah mempunyai kesiapan fisik untuk menjadi calon ibu. Kesiapan pengetahuan remaja terhadap materi tumbuh kembang balita sebesar $63,7 \%$. Tingkat kesiapan fisik dan pengetahuan remaja menjadi calon ibu sebesar $31,3 \%$. Tidak ada hubungan antara karakteristik keluarga dan sumber informasi dengan kesiapan remaja perempuan SMU di Jakarta Timur untuk menjadi calon ibu.

Kata kunci: kesiapan fisik, pengetahuan, remaja. 
$\mathcal{R}$ emaja adalah kelompok orang yang berumur $10-20$ tahun. ${ }^{1}$ Masa remaja merupakan masa terjadinya perubahan besar dan cepat pada proses pertumbuhan fisik, kognitif, dan psikososial. ${ }^{2-4}$ Masa ini berperan besar menentukan masa depan bangsa, karena remaja perempuan sebagai calon ibu memiliki risiko kehamilan dan persalinan, serta terpapar kepada masalah kesehatan lain yang berdampak pada kesehatan mental, keadaan ekonomi dan kesejahteraan sosial jangka panjang. ${ }^{5-7}$ Dua puluh tiga persen penduduk Indonesia adalah remaja, hanya 11,6\% lulusan SMU yang berkesempatan melanjutkan ke perguruan tinggi, mereka yang tidak melanjutkan antara lain memasuki jenjang perkawinan. Remaja yang memasuki jenjang perkawinan, dari segi fisik dan pengetahuan belum memadai. ${ }^{8,9}$ Data menunjukkan bahwa $21,5 \%$ perempuan Indonesia memasuki perkawinan di bawah usia 17 tahun. ${ }^{10}$ Perkawinan berusia muda mengundang risiko khususnya pada bayi, berupa bayi berat lahir rendah (BBLR), prematuritas, asfiksia, ${ }^{11-}$ ${ }^{14}$ dengan akibat jangka panjang berupa keterlambatan perkembangan motorik dan kognitif., ${ }^{1,12-15}$ Oleh sebab itu remaja perempuan sudah harus dipersiapkan, baik secara fisik (gizi baik, tidak anemia), maupun pengetahuan mengenai tumbuh-kembang balita.

Di Indonesia anemia defisiensi besi pada remaja masih merupakan masalah utama. Terdapat 51,5\% remaja perempuan yang anemia. Anemia pada remaja akan berdampak pada produktivitas, konsentrasi belajar menurun. ${ }^{1,10,14-15}$ Bila remaja perempuan tersebut memasuki usia perkawinan mereka akan hamil dengan status gizi yang rendah, karena membutuhkan peningkatan asupan energi dan zat gizi untuk pertumbuhan dirinya sendiri dan bayi yang dikandung. Ibu hamil yang menderita malnutrisi mengakibatkan tingginya angka kejadian BBLR dan lahir mati. ${ }^{15}$

Kesiapan pengetahuan terhadap tumbuh kembang balita sangat diperlukan bagi seorang ibu, karena seorang ibu yang mempunyai tingkat pengetahuan yang baik akan menghasilkan tumbuh-kembang balita yang baik pula, khususnya pada periode usia tiga tahun pertama,

\section{Alamat korespondensi:}

Dr. Soedjatmiko, Sp.A(K), Msi.

Divisi Tumbuh Kembang Pediatri Sosial. Departemen Ilmu Kesehatan Anak FKUI-RSCM. Jl. Salemba no. 6, Jakarta 10430.

Telepon: 021-3160622. Fax.021-3913982

Dr. Wan Nedra, Sp.A karena kurun usia tersebut merupakan periode pertumbuhan otak yang cepat. Stimulasi dini pada masa pertumbuhan ini sangat berperan besar, karena sangat berpengaruh terhadap proses otak. Apabila masa ini terlewatkan, yaitu otak tidak mendapat stimulasi yang memadai, sulit bagi otak untuk diprogram ulang pada masa selanjutnya. Stimulasi dini yang dilakukan oleh ibu akan dapat meningkatkan kemampuan bahasa dan emosional sosial yang terlihat setelah usia 24 bulan. ${ }^{13,16}$ Mempersiapkan remaja sebagai calon ibu yang terdidik pada saatnya menjadi seorang ibu, dapat memberikan dampak baik pada perkembangan emosi, intelektual, dan kognitif anaknya. ${ }^{12,17-20}$

Penelitian Soedjatmiko dan kawan-kawan ${ }^{21}$ tentang pengetahuan remaja perempuan terhadap tumbuh kembang balita, menunjukkan bahwa remaja perempuan yang mengerti tentang cara pemantauan pertumbuhan sebesar $80,2 \%$, dan mengerti tentang perkembangan sebesar $83,2 \%$. Lebih dari separuh remaja perempuan $(64,5 \%)$ mempunyai pengetahuan yang kurang mengenai tingkat pengetahuan cara pemberian ASI, yang mengetahui ASI ekslusif hanya $13,6 \%$, ASI on demand $27,6 \%$, yang mengetahui makanan untuk balita yang baik hanya $31,7 \%$, yang tidak tahu jadwal imunisasi 97\%. Penelitian tersebut di atas mengevaluasi pengetahuan remaja tentang tumbuh-kembang balita dengan besar sampel yang terbatas yaitu remaja dari satu SMU 1 kelas, sehingga peneliti mencoba mengembangkan penelitian tersebut. Tujuan penelitian ini untuk mengetahui seberapa jauh kesiapan fisik dan pengetahuan remaja perempuan murid SMU dalam membina tumbuh kembang balita.

\section{Metoda}

Penelitian ini merupakan suatu penelitian survei yang bersifat cross-sectional (potong lintang), dilaksanakan dengan pendekatan deskriptif analitik. Populasi penelitian ini dipilih remaja perempuan di tujuh SMU di Jakarta Timur. Waktu penelitian 3 bulan, Januari 2006 sampai dengan Maret 2006, jumlah subyek 383 orang.

\section{Hasil penelitian dan pembahasan}

Usia remaja dalam penelitian ini berkisar 15-20 tahun, remaja dalam kelompok usia tersebut lazimnya mempunyai karakter tertentu, antara lain lebih selektif 
mencari teman sebaya, mempunyai citra jasmani dirinya, dapat mewujudkan rasa cinta, dan mampu berpikir abstrak. ${ }^{16,22-24}$ Hasil penelitian ini menunjukkan bahwa $90 \%$ responden berkeinginan melanjutkan pendidikan ke perguruan tinggi, berbeda dengan data nasional yang menunjukkan hanya 11,6\% yang melanjutkan ke perguruan tinggi (Tabel 1). Keadaan ini memberikan gambaran bahwa responden pada umumnya dibesarkan dalam lingkungan keluarga dengan tingkat sosial ekonomi yang baik, yaitu 83\% ayah bekerja dan $27 \%$ ibu bekerja pula. Dibandingkan dengan negara maju seperti di Inggris, 95\% remaja melanjutkan ke perguruan tinggi dan yang 5\% sudah dipersiapkan untuk menjadi tenaga kerja sesuai dengan keinginan mereka. ${ }^{25}$

Responden yang mempunyai saudara kurang dari 3 orang ditemukan sebanyak $70 \%$, dengan komposisi jenis kelamin saudara sekandung tersebut $67 \%$ ada

Tabel 1. Sebaran subyek penelitian menurut karakteristik demografi.

\begin{tabular}{lcc}
\hline Variabel & Frekuensi $(\mathbf{n}=383)$ & $\%$ \\
\hline Umur & & \\
$\quad 15-17$ tahun & 243 & 63,4 \\
$\quad 18-20$ tahun & 140 & 36,6 \\
Suku & & \\
$\quad$ Betawi & 56 & 14,6 \\
$\quad$ Sunda & 43 & 11,2 \\
$\quad$ Jawa & 154 & 40,2 \\
Batak & 35 & 9,1 \\
$\quad$ Lainnya & 95 & 24,8 \\
Tinggal dengan siapa & & \\
$\quad$ Bapak-ibu & 290 & 75,7 \\
$\quad$ Bapak saja & 19 & 5,0 \\
$\quad$ Ibu saja & 33 & 8,6 \\
$\quad$ Nenek/paman/bibi/ & & \\
keluarga lain & 39 & 10,2 \\
$\quad$ Kos/menyewa/mandiri & 2 & 0,5 \\
Jumlah saudara (orang) & & \\
$\quad \leq 3$ (keluarga kecil) & 267 & 69,7 \\
$\quad \geq 3$ (keluarga Besar) & 116 & 30,3 \\
Jenis kelamin saudara & & \\
$\quad$ Laki-laki semua & 42 & 11,0 \\
Ada yang perempuan & 257 & 67,1 \\
$\quad$ Perempuan semua & 84 & 21,9 \\
Keinginan ke perguruan tinggi & & \\
$\quad$ Tidak & 38 & 9,9 \\
$\quad$ Ya & 345 & 90,1 \\
\hline
\end{tabular}

yang perempuan, ada perbedaan tema komunikasi antar saudara berdasarkan jenis kelamin tersebut; interaksi yang rapat pada saudara-saudara sekandung cenderung mendorong pengetahuan yang didapat dirumah akan melekat lebih kuat pada ingatan seseorang. ${ }^{24}$

\section{Status gizi dan kadar hemoglobin responden}

Status gizi merupakan manifestasi keadaan tubuh, yang dapat mencerminkan hasil makanan yang dikonsumsi setiap hari. Untuk meningkatkan kualitas tumbuh kembang balita, gizi baik dimulai sejak dalam kandungan. Sebaiknya perempuan sebelum hamil mempunyai gizi baik sehingga dapat mencegah komplikasi pada bayi, bila terdapat gizi kurang akan melahirkan bayi kecil untuk masa kehamilan, sedangkan ibu yang obesitas akan berdampak pada meningkatnya komplikasi persalinan, sehingga gizi baik merupakan salah satu faktor pranikah yang harus dipersiapkan untuk calon ibu. ${ }^{15}$ Meskipun tidak ada penelitian khusus yang mendokumentasikan efek dan dampak krisis ekonomi terhadap outcome kehamilan, tetapi penelitian yang dilakukan akhir-akhir ini menunjukkan dengan jelas bahwa bayi yang lahir dari ibu-ibu yang mengalami malnutrisi mempunyai ratarata berat lahir 2.568 gram atau 390,9 gram lebih rendah dibandingkan rata-rata berat lahir bayi dari ibuibu yang tidak mengalami malnutrisi. Ibu hamil yang mengalami malnutrisi mempunyai risiko melahirkan bayi dengan berat lahir rendah (BBLR) 5 kali lebih besar dibandingkan ibu hamil yang tidak malnutrisi. ${ }^{15}$ Pada penelitian ini diperoleh gambaran gizi kurang sebesar $18,5 \%$, obesitas $2,3 \%$. Remaja pada kelompok ini berisiko tinggi untuk menjadi calon ibu.

Anemia pada responden penelitian ini ditemukan sebesar 25,3\%, dibandingkan dengan data dari Kabupaten Tangerang (2005) 22\%, Bogor 44\%, Bandung 40-41\% dan Kupang (2001) 4,17\%. ${ }^{15}$ Penelitian ini hampir sama dengan hasil Survei Kesehatan Rumah Tangga (SKRT 2001) yang mendapatkan anemia sebesar $26,5 \%$. Penyebab anemia pada remaja perempuan adalah kekurangan cadangan besi, kelainan hemoglobin (hemoglobinopati/ hemoglobin tidak mampu menggunakan besi untuk membentuk sel darah merah), kekurangan zat gizi lain seperti vitamin A, asam folat, seng dan vitamin B12. 
Penyebab lain dipikirkan juga kehilangan zat besi pada saat menstruasi. Penanganan anemia pada remaja perempuan akibat kekurangan cadangan besi adalah suplementasi besi minimal selama 120 hari, sesuai dengan umur sel darah merah. ${ }^{26}$ Masalah gizi di Indonesia tahun 2001 hingga 2003 menunjukkan 3,5 juta remaja dan wanita usia subur menderita anemia defisiensi besi. Dampak yang terjadi bila pada masa remaja sebagai calon ibu mengalami anemia, pada kehamilan akan menghasilkan neonatus dengan kerusakan otak permanen. Meningkatkan status besi pada remaja perempuan sebelum memasuki kehamilan menjadi penting karena akan mempersiapkan mereka menjadi calon ibu yang sehat, sejalan dengan peningkatan status gizinya. ${ }^{15,27}$ (Tabel 2)

Tabel 2. Sebaran menurut status gizi dan kadar hemoglobin

\begin{tabular}{lcc}
\hline Variabel & Jumlah $(\mathbf{n}=\mathbf{3 8 3})$ & $\%$ \\
\hline Status gizi & & \\
$\quad$ Gizi kurang & 71 & 18,5 \\
$\quad$ Gizi baik & 285 & 74,4 \\
$\quad$ Gizi lebih & 18 & 4,7 \\
$\quad$ Obesitas & 9 & 2,3 \\
Kadar hemoglobin ${ }^{* *}(\mathrm{~g} / \mathrm{dl})$ & & \\
$\quad<12$ & 97 & 25,3 \\
$>12$ & 286 & 74,7 \\
\hline
\end{tabular}

* Sesuai dengan IMT

** Batas $12 \mathrm{~g} / \mathrm{dl}$ untuk remaja

\section{Pengetahuan responden}

Pengetahuan tentang tumbuh kembang menjadi indikator yang diukur sebagai variabel terikat. Pengetahuan menjadi salah satu komponen kesiapan remaja untuk menjadi calon ibu yang dapat membina tumbuh kembang balita. Pengetahuan yang ditanyakan dalam kuesioner adalah materi dasar tumbuh kembang yang mestinya dimiliki oleh calon ibu. Penilaian pengetahuan responden didasarkan pada jumlah jawaban benar dari 33 pertanyaan yang diajukan, bobot nilai masing-masing pertanyaan adalah 1 , maka diharapkan nilai tertinggi 33. Pengetahuan baik bila nilai lebih dari $75 \%$ yang betul, pengetahuan sedang bila lebih dari $50 \%$ dan pengetahuan kurang bila nilai di bawah 50\%. Responden pada penelitian ini yang berpengetahuan tinggi hanya 19\%, berpengetahuan sedang 33\% dan rendah 48\%. Dibandingkan dengan penelitian yang dilakukan di Brazil (1999) tentang pengetahuan dasar tumbuh kembang balita pada responden remaja hamil yang datang ke klinik, 60\% berpengetahuan rendah. ${ }^{27}$ Studi yang dilakukan di India, untuk mengetahui pengetahuan remaja sebagai ibu muda terhadap pengetahuan tumbuh kembang balita, menunjukkan 39\% responden berpengetahuan sedang, 32\% tinggi dan 29\% rendah. Terdapat hubungan yang signifikan antara pengetahuan dengan variabel demografi. Hipotesis yang dirumuskan oleh peneliti tersebut telah didukung oleh studi yang menyatakan bahwa ibu/pengasuh dengan pengetahuan tinggi akan mengurangi risiko BBLR. ${ }^{28}$

Studi di Amerika menunjukkan bahwa ibu remaja yang diberikan intervensi pengetahuan tumbuh kembang balita mempunyai bayi dengan perkembangan baik, imunisasi lengkap; dibandingkan dengan ibu sebagai kontrol yang tidak diberikan intervensi. Pengetahuan tumbuh kembang balita pada remaja berpengaruh pada kepercayaan remaja tersebut merawat balitanya. ${ }^{29}$

Survei World Fertility di Amerika mengenai pengetahuan tumbuh kembang balita pada ibu remaja (usia 13 - 19 tahun) dibandingkan dengan ibu yang lebih tua (usia 20 - 41 tahun), mendapatkan bahwa pengetahuan kedua kelompok tersebut diketahui berhubungan secara signifikan dengan percaya diri dan kepedulian si ibu terhadap perawatan bayinya. ${ }^{30}$ Penelitian lain mendapatkan bahwa pengetahuan tumbuh kembang ibu sangat penting untuk mengurangi angka kematian balita. Ibu yang berpengetahuan tinggi akan meningkatkan percaya diri ibu dalam merawat balita sebanyak $15 \%$, sehingga penelitian ini merekomendasikan pemberian materi tumbuh kembang pada remaja di sekolah. ${ }^{29}$

Hasil evaluasi materi pengetahuan dasar tumbuh kembang pada responden penelitian ini menunjukkan bahwa remaja yang mengerti cara pemantauan tumbuh-kembang didaptkan sebesar 80\% (Tabel 3). Penelitian ini hampir sama dengan penelitian Soedjatmiko dkk. yang memperoleh angka 80,2\%, namun lebih lanjut ditanyakan tentang kriteria pertumbuhan yang baik, ternyata hanya 50-60\% yang menjawab benar, sedangkan penelitian Soedjatmiko dkk. ${ }^{21}$ mendapatkan hasil lebih tinggi yaitu $80,2 \%$. Perlu pemberian edukasi secara berkesinambungan kepada remaja tentang tumbuh kembang balita, oleh orang tua atau guru di sekolah atau melalui media masa. Cara pemberian ASI yang benar diketahui oleh 
Sari Pediatri, Vol. 8, No. 3, Desember 2006

Tabel 3. Distribusi frekuensi responden berdasarkan pengetahuan remaja perempuan sebagai calon ibu dalam membina tumbuh kembang balita.

\begin{tabular}{|c|c|c|c|}
\hline No & Materi & Jawaban benar & $\begin{array}{c}\text { Jawaban Salah/ } \\
\text { tidak lengkap }\end{array}$ \\
\hline \multicolumn{2}{|c|}{ Tumbuh kembang (TK) } & $\%$ & $\%$ \\
\hline 1 & Apa yang disebut pertumbuhan balita? & 76,8 & 16,4 \\
\hline 2 & Apa yang disebut perkembangan balita? & 67,2 & 32,8 \\
\hline 3 & Apa yang dimaksud pertumbuhan yg baik? & 60,2 & 39,8 \\
\hline 4 & Apa yang dimaksud perkembangan yg baik? & 64,5 & 35,5 \\
\hline 5 & Bagaimana mengetahui TK yang baik? & 86,8 & 13,2 \\
\hline 6 & Umur berapa balita tengkurap sendiri? & 82,8 & 16,6 \\
\hline 7 & Umur berapa balita duduk? & 80,8 & 19,2 \\
\hline 8 & Umur berapa balita berdiri tanpa berpegangan? & 64,2 & 35,8 \\
\hline 9 & Umur berapa balita berjalan lancar? & 70,2 & 29,8 \\
\hline 10 & Umur berapa balita berbicara dengan kata-kata yang dapat dimengerti? & 66,2 & 33,8 \\
\hline \multicolumn{4}{|c|}{ Stimulasi dini } \\
\hline 11 & Bagaimana menstimulasi kemampuan bahasa balita? & 83 & 17 \\
\hline 12 & Bagaimana menstimulasi gerakan balita? & 72,8 & 27.2 \\
\hline \multicolumn{4}{|c|}{ Imunisasi } \\
\hline 13 & Pada umur berapa anak harus diberi imunisasi lengkap? & 70,4 & 29,6 \\
\hline 14 & Jenis imunisasai yang diberikan pada usia 9 bulan? & 63,2 & 36,8 \\
\hline 15 & Apa efek samping imunisasi bila diberikan pada balita? & 69,6 & 30,4 \\
\hline \multicolumn{4}{|c|}{ Pemberian vitamin A } \\
\hline 16 & Apa manfaat vitamin A bagi anak? & 78,2 & 21,8 \\
\hline 17 & Apa saja jenis makanan yang mengandung vitamin $A$ ? & 73,6 & 26,4 \\
\hline 18 & Berapa kali dalam setahun anak diberikan vitamin A? & 60,7 & 39,3 \\
\hline \multicolumn{4}{|c|}{ Anemia } \\
\hline 19 & Apa yang disebut dengan anemia? & 54,9 & 45,1 \\
\hline 20 & Apa penyebab anemia yang tersering pada remaja perempuan? & 68,4 & 31,6 \\
\hline \multicolumn{4}{|c|}{ ASI ekslusif \& makanan pengganti ASI } \\
\hline 21 & Apa yang disebut ASI eksklusif? & 71,9 & 28,1 \\
\hline 22 & Kolustrum adalah ASI yang pertama keluar, apa manfaat kolostrum? & 74,4 & 25,6 \\
\hline 23 & Bagaimana cara memberikan ASI yang baik? & 70,8 & 29,2 \\
\hline 24 & Makanan apa yang dapat memperlancar ASI? & 73,3 & 26,7 \\
\hline 25 & Apa makanan balita yang baik pada usia 6 bulan? & 83,4 & 16,6 \\
\hline \multicolumn{4}{|c|}{ Penyakit yang perlu diwaspadai di rumah $\&$ penanganan darurat } \\
\hline 26 & Penyakit apa yang sering diderita anak di rumah? & 88 & 12 \\
\hline 27 & Jika anak diare, maka sebaiknya diberikan: & 79,9 & 20,1 \\
\hline 28 & Apa faktor penyebab diare? & 63,9 & 36,1 \\
\hline 29 & Apa tanda-tanda anak sakit? & 52,1 & 47,9 \\
\hline 30 & Apa yang harus dilakukan jika anak sakit tambah parah? & 55,5 & 44,5 \\
\hline 31 & Obat pertolongan pertama apa yang perlu disediakan di rumah? & 87,7 & 12,3 \\
\hline 32 & Apa kegunaan parasetamol? & 75,1 & 24,9 \\
\hline 33 & Bagaimana mencegah anak mengalami kecelakaan? & 80,2 & 19,8 \\
\hline
\end{tabular}

$75 \%$ responden, berbeda dengan penelitian Soedjatmiko yang mendapatkan hasil hanya 35\%. Keadaan ini disebabkan karena media sosialisasi ASI oleh pemerintah sudah dapat diandalkan. Pada penelitian ini, $60-70 \%$ responden mempunyai pengetahuan tentang jadwal imunisasi, sedangkan 
penelitian Soedjatmiko menemukan 97\% tidak tahu. Program imunisasi pemerintah masih harus terus disosialisasikan kepada masyarakat, begitu juga pada remaja yang akan melaksanakannya bagi anak-anak mereka bila sudah menjadi ibu.

Untuk pertanyaan stimulasi dini, cara stimulasi kemampuan bahasa dan cara stimulasi perkembangan, remaja yang menjawab benar lebih dari $70 \%$, namun kuesioner yang digunakan pada penelitian tidak menggali lebih dalam kemampuan pengetahuan stimulasi dini tersebut. Tentang manfaat dan jenis makanan yang mengandung vitamin $\mathrm{A}$, responden yang menjawab benar lebih dari $70 \%$, namun yang mengetahui frekuensi pemberian vitamin A hanya $60 \%$. Tentang anemia, hanya $50-60 \%$ responden yang mengetahui apa yang disebut anemia dan penyebab anemia.

Tujuh puluh persen responden mengetahui cara mengatasi diare di rumah, namun pengetahuan tentang faktor penyebab diare sangat rendah sekali, hanya $40 \%$ responden yang mengetahuinya. Begitu juga pengetahuan responden mengenai tanda-tanda seorang anak menderita sakit dan bertambah parah di rumah kemudian harus segera dirujuk, masih rendah, yaitu hanya $50-55 \%$ yang menjawab benar. Responden menguasai dengan baik pengetahuan obat-obatan yang harus disediakan di rumah, seperti parasetamol dan upaya mencegah kecelakaan.

\section{Gambaran sumber informasi}

Sumber informasi yang berhubungan dengan topik tumbuh kembang balita hanya $13.6 \%$ diperoleh dari sumber formal (sekolah, orang tua dan tenaga kesehatan), 86.4\% mendapatkan informasi dari sumber informal yaitu media surat kabar/majalah, radio, televisi, dengan frekuensi hampir setiap hari dan atau paling sedikit sekali/minggu. Walaupun pengetahuan dasar tumbuh kembang dijawab dengan baik, namun misinformasi dapat saja terjadi karena sumber informasi lebih banyak dari sumber informal, sehingga perlu peningkatan pengetahuan dan keterampilan orang tua dan guru sebagai sumber informasi terdekat dengan remaja. ${ }^{22,23}$ Responden yang terpapar dengan media informasi, baik elektronik maupun majalah/buku, didapatkan sebanyak $86,4 \%$ terpapar dan $13,6 \%$ jarang terpapar.

\section{Gambaran demografi keluarga}

Sebagian besar tingkat pendidikan orang tua responden adalah pendidikan menengah (SMU atau sederajat), namun masih terdapat $19,3 \%$ ayah berpendidikan rendah, dan $32,6 \%$ ibu berpendidikan rendah. Terdapat $16,6 \%$ ayah tidak bekerja, 7,9\% ayah bekerja sebagai buruh, petani dan pedagang kaki lima. Ayah yang bekerja menjadi PNS, BUMN dan swasta sebesar $75,4 \%$. Ibu sebagian besar berperan sebagai ibu rumah tangga $(72,8 \%)$, dan $27,2 \%$ ibu membantu keuangan keluarga dengan bekerja sebagai PNS 9,1\%, pegawai swasta $5 \%$, wiraswasta $5 \%$, BUMN 10,2\%, buruh, petani, pedagang kaki lima sebanyak 3,1\%. Kebanyakan responden berasal dari suku Jawa.

\section{Gambaran kesiapan responden untuk menjadi calon ibu yang dapat membina tumbuh kembang balita}

Kesiapan remaja perempuan sebagai calon ibu dalam membina tumbuh kembang balita terdiri dari 3 kategori kesiapan. Kategori pertama, kesiapan fisik, kategori kedua kesiapan pengetahuan dan ketiga kesiapan fisik dan pengetahuan. Kesiapan fisik adalah gizi baik dan gizi lebih, serta tidak anemia. Kesiapan pengetahuan adalah responden yang memiliki pengetahuan baik, sedangkan kesiapan fisik dan pengetahuan adalah gizi baik, gizi lebih, tidak anemia dan berpengetahuan baik.

Dari segi kesiapan fisik, didapatkan jumlah responden yang tidak siap untuk menjadi calon ibu sebanyak $42,3 \%$. Sedangkan responden yang mempunyai kesiapan pengetahuan sebanyak 63,7\%. Dari segi kesiapan fisik dan pengetahuan, responden yang tidak siap untuk menjadi calon ibu sebanyak 263 orang $(68,7 \%)$ dan yang siap sebanyak 120 orang $(31,3 \%)$. (Tabel 4)

\section{Hubungan antara kesiapan responden dengan demografi keluarga dan media informasi}

Demografi keluarga dan media informasi merupakan faktor-faktor yang mempengaruhi kesiapan remaja untuk menjadi calon ibu, namun hasil uji statistik menunjukkan tidak ada hubungan antara kesiapan 
Tabel 4. Distribusi responden menurut kesiapan fisik dan kesiapan pengetahuan

\begin{tabular}{lcc}
\hline Kesiapan jadi calon ibu & Frekuensi $(\mathbf{n}=383)$ & $\%$ \\
\hline Kesiapan fisik & & \\
$\quad$ Tidak siap & 162 & 42.3 \\
$\quad$ Siap & 221 & 57.7 \\
Kesiapan pengetahuan & & \\
$\quad$ Tidak siap & 139 & 36.3 \\
$\quad$ Siap & 244 & 63.7 \\
Kesiapan fisik dan Pengetahuan & & \\
$\quad$ Tidak siap & 263 & 68.7 \\
$\quad$ Siap & 120 & 31.3 \\
\hline
\end{tabular}

responden dengan demografi keluarga dan media informasi (chi square, $\mathrm{p}>0,05$ ), maka analisis multivariat tidak dapat dilakukan.

\section{Keterbatasan penelitian}

Peneliti sangat menyadari bahwa penelitian ini memiliki banyak kekurangan dan keterbatasan, baik dalam mengemukakan ide/konsep, dana dan waktu yang terbatas untuk pengumpulan data antropometri, pemeriksaan fisis dan pemeriksaan laboratorium. Teknik pengambilan sampel berkaitan erat dengan kelemahan cara pengambilan sampel, sehingga tidak memberikan gambaran keadaan populasi yang sebenarnya. Kelemahan tersebut telah dicoba diatasi dengan cara melakukan pengambilan sampel di sekolah dengan cara acak sederhana, namun ternyata tidak cukup untuk mengatasi kelemahan tersebut.

\section{Kesimpulan}

Berdasarkan status gizi dan kadar hemoglobin didapatkan bahwa $57,7 \%$ remaja perempuan siswi SMU di Jakarta Timur telah mempunyai kesiapan fisik untuk menjadi calon ibu. Tingkat kesiapan pengetahuan tentang tumbuh kembang balita dimiliki oleh $63,7 \%$ remaja. Tingkat kesiapan fisik dan pengetahuan remaja menjadi calon ibu didapatkan pada $37,6 \%$. Tidak ada hubungan antara karakteristik keluarga dan sumber informasi dengan kesiapan remaja perempuan siswi SMU di Jakarta Timur untuk menjadi calon ibu.

\section{Saran}

Bagi remaja, untuk dapat mempersiapkan diri menjadi calon ibu yang akan dapat membina tumbuh kembang balita, tambahan pengetahuan dan wawasan terhadap tumbuh kembang balita perlu ditingkatkan melalui pemanfaatan media yang ada, kegiatan ekstra dan juga pengetahuan yang diberikan oleh guru di sekolah serta orang tua di rumah. Pendidikan gizi yang diutamakan adalah penekanan informasi anemia serta adanya zatzat gizi yang harus dipenuhi pada masa remaja. Pengukuran kadar hemoglobin perlu dilakukan minimal 1 tahun sekali. Sebaiknya kegiatan monitor dan penilaian status gizi diteruskan pelaksanaannya melalui Usaha Kesehatan Sekolah (UKS) yang telah ada.

Bagi orang tua, untuk meningkatkan pengetahuan tumbuh kembang balita agar dapat berperan aktif dalam memberikan pengetahuan kepada remaja. Aktif mengawasi aktivitas anak-anaknya di luar sekolah terhadap keterpaparan media informasi.

Bagi para peneliti lain, perlu dilakukan kembali penelitian dengan penyempurnaan konsep dan jumlah subyek yang lebih banyak, sehingga hasil analisis dapat mewakili populasi remaja di Indonesia. Penelitian akan lebih baik bila setelah mendapatkan data dasar dilakukan intervensi berupa edukasi sehingga pemahaman akan pentingnya tumbuh kembang balita bagi remaja dapat benar-benar menjadi bekal/referensi untuk mempersiapkan diri menjadi calon ibu. Selanjutnya dilakukan evaluasi setelah intervensi tersebut.

Bagi Pemerintah, Departemen Kesehatan, BKKBN, Pendidikan Nasional, dan Kementerian Pemberdayaan Perempuan, diharapkan dapat merumuskan upaya strategis dan menyusun modul untuk remaja agar mendukung program tumbuh kembang anak Nasional untuk mewujudkan sumber daya manusia (SDM) yang berkualitas sejak pra-nikah. Materi tumbuh kembang perlu dijadikan salah satu topik dalam kurikulum di sekolah, tingkatannya disesuaikan dengan usia remaja. Membuat paket khusus (kursus singkat) dengan materi tumbuh kembang anak-remaja untuk calon pengantin. Kursus ini diwajibkan untuk remaja yang akan menikah.

\section{Daftar Pustaka}

1. Renee JR. Special health problems during adolescence. Dalam: Nelson WE, Behrman RE, Kliegman RM, Jenseon HB, penyunting. Nelson's textbook of pediat- 
rics. Edisi ke-17. Philadelphia: WB Saunders; 2000. h. 553-83.

2. Darmosubroto S. Masa kritis tumbuh kembang anak pada masa adolesen/remaja. Dalam: Sularyo TS, Musa DA, Gunardi H, penyunting. Deteksi dan intervensi dini penyimpangan tumbuh kembang anak dalam upaya optimalisasi kualitas sumber daya manusia, naskah lengkap Pendidikan Kedokteran Berkelanjutan Ilmu Kesehatan Anak FKUI XXXVII, Jakarta: Balai Penerbit FKUI; 1996. h. 40-5.

3. Mac Kenzie RC. Global prospective on reproductive health issues in adolescence females. Kumpulan makalah temu tahunan VIII Jaringan Epidemiologi Nasional, 2428 November 1998.

4. Achir YCA. Program pembinaan dan pengembangan remaja. Tulisan dipresentasikan di KONIKA XI. Jakarta, 4-7 Juli 1999.

5. Survei Masalah Remaja. Diunduh dari: http://situs. kesrepro.info/krr/. Diakses tanggal 11 Desember 2004.

6. Alisjahbana A. Meeting the needs of young people in Indonesia a country report. Dalam: Soetjiningsih, Rubiana S, Subadana IB, Putra IGN, Sutriani MD, penyunting. Proceedings book. $12^{\text {th }}$ National Congress of child Health and $11^{\text {th }}$ ASEAN Pediatrics Federation Conference. Volume 1. Bali; 2002. h. 81-8.

7. Mensch BS, Bruce B, Greene ME. The undercharted passage: girls adolescence in developing world. Population Council, New York 1988.

8. Perempuan putus sekolah harus tetap mendapatkan pendidikan. Diunduh dari: http://www.mediaindo.co.id. Diakses tanggal 3 Oktober 2005.

9. Unicef. Investasi bangsa melalui pendidikan dasar 9 tahun. Pusat Kajian Ekonomi Kesehatan Universitas Indonesia. Diunduh dari: www.unicef.org.id. Diakses tanggal 4 Juni 2005.

10. Wahyudis R. Kesehatan reproduksi remaja : PKBI DKI Bekerjasama dengan IPPF dan UNFPA. Diunduh dari http://situs.kesrepro.info/krr/ Diakses tanggal 4 Juli 2004.

11. Unicef. Adolescence. Dalam: Challenges for a new generation the situation of children and woman in Indonesia. September 2000.

12. Wijaya TS. Epidemiologi masalah remaja. Dipresentasikan di KONIKA XI 1999, Jakarta.

13. Ismail S. Beberapa aspek pertumbuhan dan perkembangan anak Indonesia. Dalam: Symposium \& workshop towards optimal child growth and development, Jakarta 2003.

14. Ismail S. Tumbuh kembang anak dalam pencapaian potensi sumber daya manusia yang tangguh. Disam- paikan pada Pidato Pengukuhan Guru Besar FKUI. Jakarta 1991.

15. Hadi H. Beban ganda masalah gizi dan implikasinya terhadap kebijakan pembangunan kesehatan nasional. Disampaikan pada Pidato pengukuhan jabatan guru besar FK UGM. Yogyakarta, 2005.

16. Soedjatmiko. Peningkatan kelangsungan hidup dan tumbuh kembang Balita melalui pemberdayaan remaja putri, ibu, keluarga dan masyarakat. Majalah Kesehatan Masyarakat Indonesia. 2001; 21:5-6.

17. Ayuboub C, Pan B, Guinee K, Russell C. Relationships between family characteristics and young children's language and socio-emotional development in families eligible for early head start. Diunduh dari http:// www.pediatrics. Diakses tanggal 16 Februari 2005.

18. Soedjatmiko. Stimulasi dini. Disampaikan pada symposium dan workshop towards optimal child growth and development. Jakarta, 12-14 September 2003.

19. Soedjatmiko. Stimulasi psikososial pada bayi risiko tinggi. Dalam: Trihono PP, Purnamawati, Syarif DR, penyunting. Hot topics in pediatrics II. Naskah lengkap Pendidikan Kedokteran Berkelanjutan Ilmu Kesehatan Anak FKUI XLV. Jakarta: Balai Penerbit FKUI; 2002. h. 28-46.

20. Rosdiana D. Pokok-pokok pikiran pendidikan seks untuk remaja. Dalam: Kollman N, penyunting. Kesehatan reproduksi remaja. Jakarta: Yayasan Lembaga Konsumen Indonesia;1998. h. 9-20.

21. Soedjatmiko, Gunardi H, Sularyo TS, Musa DA, Darmosubroto S. Peran remaja putri sebagai kakak dan calon ibu dalam membina tumbuh kembang balita. Dipresentasikan pada Konika XI , Jakarta 4-7 Juli 1999.

22. Notoatmodjo S. Pendidikan kesehatan dan ilmu perilaku dalam masyarakat. Dalam: Notoatmodjo S, Waryuningsih E, penyunting. Pendidikan promosi dan perilaku kesehatan. Teori dan aplikasi KMP-600. Jakarta: FKM UI; 2000. h. 3-9.

23. Kartono K. Psikologi wanita. mengenal gadis remaja dan wanita dewasa. Bandung: Mandar Maju 1992. h. 10711.

24. Krianto T. Pemberdayaan masyarakat dalam promosi kesehatan. Dalam Notoatmojo S, penyunting. Promosi Kesehatan Teori dan Aplikasi. penyunting.Edisi pertama. Jakarta: Rineka Cipta; 2005. h. 254-80.

25. Undergraduate programmes. Diunduh dari http:// www. Tasc.ac.uk. Diakses tanggal 11 November 2005.

26. Indriastuti YA. Pengaruh suplementasi besi-seng pada status besi-seng dan kejadian sakit pada murid remaja 
Sari Pediatri, Vol. 8, No. 3, Desember 2006

putri anemia di kabupaten Tangerang: Disertasi. Jakarta, 2005.

27. Caldwell J, McDonald P. Influence of maternal education on infant and child mortality: levels and causes. Diunduh dari http: // www.pediatrics. Diakses tanggal 16 Februari 2005.

28. The Effect of a Parenting Education Program on the Use of Preventive Pediatric Health Care Services Among Low-Income, Minority Mothers: A Randomized, Controlled Study. Diunduh dari: http:// www.pediatrics.org/cgi/content/full. Diakses tanggal 14 Februari 2006.

29. A study to assess the knowledge of mother's about risk factors of low birth weight. Diunduh dari http: // www.findarticles.com/p/search. Diakses tanggal 2 Februari 2006.

30. Ruchala PL, James DC. Social support, knowledge of infant development, and maternal confidence among adolescent and adult mothers. J Obstet Gynecol Neonatal Nurs 1997. h. 685-9 